International Journal of Social Science And Human Research

ISSN(print): 2644-0679, ISSN(online): 2644-0695

Volume 05 Issue 01 January 2022

DOI: 10.47191/ijsshr/v5-i1-27, Impact factor-5.586

Page No: 183-188

\title{
The Influence of the State Budget of Income and Expenditure on the Defense Budget
}

\author{
Korinti Venesia Pandia ${ }^{1}$ Yudi Sutrasna ${ }^{2}$, Djoko Andreas Navalino ${ }^{3}$, Susilo Adi Purwantoro ${ }^{4}$, \\ Luhut Simbolon ${ }^{5}$, Lukman Yudho Prakoso ${ }^{6}$ \\ 1,2,3,4,5,6 Defense Economics Study Program-Faculty of Defense Management, Republic Indonesia Defense University. J1. Salemba \\ No.14 Jakarta Pusat
}

\begin{abstract}
The economic war that was going on between strong countries such as America and China had a wide impact on various countries including Indonesia. This study aims to examine how the Influence of the State Development and Expenditure Budget on the 2010-2020 Defense Budget. The method used in this research is quantitative. The results of the study indicate that in terms of economic growth, there are contradictions in both the estimation results and the theory, where based on the estimation results, economic growth has a significant negative effect on the defense budget. The Keynesian view is that the increase in government spending will encourage an increase in demand for various goods and services produced by the economy in aggregate so as to encourage economic growth. In other words, state spending, including defense spending, is an important and ideal policy tool used by the government in an effort to create and increase quality economic growth.
\end{abstract}

KEYWORDS: Threat, State budget, Economy, Defense

\section{INTRODUCTION}

Indonesia as an open country cannot be separated from the influence of global and regional developments. Stability and security of the strategic environment is part of Indonesia's national interest, so it is in Indonesia's interest to observe developments in situations that threaten world peace and regional stability in order to take appropriate steps. The written basic law of the Unitary State of the Republic of Indonesia which contains the legal basis and outline in the administration of the State is officially contained in the 1945 Constitution of the Republic of Indonesia (UUD 1945). Things that are very fundamental and constitutionally underlie the Doctrine of National Defense contained in the Preamble to the 1945 Constitution. At the opening, the basic principles of the implementation of state defense are imbued with Pancasila, namely "The Indonesian nation essentially loves peace but loves independence and sovereignty more. ". Furthermore, in paragraph II, the National Ideals of the Indonesian Nation are also mandated, namely "The realization of the Unitary State of the Republic of Indonesia which is independent, united, sovereign, just and prosperous" (Dipua, 2021). Indonesia is aware that its national security is part of the strategic interests of other countries. Domestic security issues that arise are also influenced by external and internal factors that have the potential to disrupt national security stability. These factors include the impact of ethnic heterogeneity in Indonesia, the economic situation that causes the burden of life to become heavier, as well as political and social factors (Prakoso, 2021).

Based on this fact, defense efforts do not only refer to traditional security issues, namely invasion or aggression from other countries, but also to non-traditional security issues, namely any actions that threaten state sovereignty, territorial integrity, and the safety of the nation and the Unitary State of the Republic of Indonesia. In the context of a country's efforts to organize national defense, the benchmark is the carrying capacity or amount of a country's defense budget which is part of the state budget. In essence, the budget is a form of government policy that is stated in numbers and is valid for a certain period of time. The defense budget is a benchmark used to see the capabilities and policies of the state in responding to the defense system used and to see the resources provided by the state to its armed forces, and the state's commitment to managing and improving defense capabilities (Suhirwan (2020).

One of the issues that has weakened the world's economic growth the most is the trade war. Trade wars between countries that cause trade tensions not only trigger a weakening of world trade in goods, but also have an impact on other economic activities such as the service sector and the labor market. This condition further confirms the economic slowdown that has spread to countries that are not only supported by the industrial sector, but also to countries that are supported by the service sector. Then the development of trade relations tensions between the ongoing trade relations resulted in the emphasis on the US and Chinese economies so that they were on a slowing trajectory (Prihantoro, 2020). 


\section{The Influence of the State Budget of Income and Expenditure on the Defense Budget}

The economic slowdown in the United States also occurred as a result of the diminishing impact of fiscal stimulus since 2018. Meanwhile, China's growth was slower than in the previous decade as a consequence of economic rebalancing policies and deleveraging of the financial system. Trade tensions ultimately hit the trade and investment activities of the two countries. In particular, Indonesia, with various phenomena and developments occurring in the global economy, will certainly have an impact on the Indonesian economy.

Based on the phenomena and previous research that has been carried out, in this study, it will be examined how the Influence of the State Development Budget and Expenditure on the 2010-2020 Defense Budget.

\section{METHOD}

The research method is a way in a study to understand an object of research that will guide researchers in the sequence of research carried out either in the form of techniques or procedures used in research. Sugiyono (2006) states that research methods can be interpreted as a scientific way to obtain valid data with the aim of being able to find, prove and develop knowledge so that it can ultimately be used to understand, solve and anticipate problems. The research method uses a scientific method to produce data with certain purposes and uses and the scientific method in question is based on rational, empirical and systematic scientific characteristics.

A study can be classified from various approaches. If viewed from the analytical approach, the research consists of two kinds, namely a quantitative approach and a qualitative approach. This study is based on the philosophy of positivism by using quantitative data analysis methods with a descriptive approach and emphasizing analysis on numerical data (numbers) starting from data collection to the results. The purpose of using this method is to mutually support the results of the analysis by testing hypotheses. predetermined (Sugiyono, 2011).

The descriptive analysis is a method used to describe or analyze a research result but is not used to make broad conclusions (Sugiyono, 2011). Descriptive analysis is used to describe research objects/data or research variables comprehensively as well as problem solving by describing or explaining the state of research objects/data or research variables that are actual in terms of theoretical studies and empirical facts that are descriptive in nature in the form of sentences, then in support the results of data analysis that is processed by quantitative analysis. In summary, the function of the descriptive method in brief is to analyze in order to find the relationship, relationship, and influence between one variable and another variable.

The hypothesis in this study will be tested using a descriptive approach where the test will be carried out in a measurable manner so that parameters can be obtained from the effect of changes in an economic variable on changes in other economic variables which can be explained with the assumption of economics (Muhammad: 2005 in Putri, 2020). Descriptive approach is used to interpret the results of quantitative testing which will later answer the hypothesis of the research conducted.

Quantitative analysis in this study will use the method of Multiple Linear Regression (Ordinary Last Square) with classical tests to determine the effect of each dependent variable on the independent variable with the help of a computer program with the Eviews application.

\section{ANALYSIS AND DISCUSSION}

The estimation results using the Ordinary Last Square method that have been carried out in this study can be seen how the variability relationship affects the increase in the Defense Budget. As for comparison with previous research, namely, the research of Saadet Deger and Somnath Sen entitled "Military Expenditure And Developing Countries" (1995) in the study stated that to understand the nature of military spending, especially in developing countries, it must go beyond the economic field. The economic sector in question is economic growth and expenditure on defense, security and development. This study found that the level of economic development, given by a standard measure of per capita income, had no effect or contradictory to military spending.

In Dogan and Cheong's (2006) research on Government Expenditure and National Income: Causality Tests For Five South East Asian Countries (Government Expenditure And National Income: Causality Tests For Five South East Asian Countries). The researcher uses the Johansen-Juselius cointegration method to detect the long-term relationship between real per capita national income and real per capita government spending in all sample countries and the methodology developed by Granger to test the two hypotheses. The results of the Granger causality test show that there is no causal relationship from real per capita income to government spending. Government spending does not play a significant role in driving economic growth in the four countries in the study.

Pieroni (2007) in his research observes how government spending has an important influence on the long-term growth rate. The researchers found a weak negative relationship between the share of military spending and economic growth. countries with lower military burdens show a non-significant relationship between military burden and growth with nonparametric estimates that 


\section{The Influence of the State Budget of Income and Expenditure on the Defense Budget}

approximate parametric analysis. In conclusion, the results confirm that the relationship between military spending and growth may contain nonlinearities other than those hypothesized.

Avatara (2013) in his research on economic growth which is influenced by Tax Revenue, Indonesian Government Debt, Capital Expenditure, and Regional Autonomy Policy and Economic Growth. The results of data analysis show that Tax Revenue, Indonesian Government Debt, Capital Expenditures and Regional Autonomy Policies simultaneously have a significant effect on Economic Growth (GDP) in Indonesia in 1992 - 2011 in terms of fiscal. Partially, tax revenues, Indonesian government debt, capital expenditures and regional autonomy policies have a positive effect on economic growth (GDP) in Indonesia in $1992-$ 2011. Partially, the variable is tax revenue (T), Indonesian government debt (UPI). Capital Expenditure (BM) and Regional Autonomy Policy (DUM) have an effect on economic growth in Indonesia (GDP). Tax revenue has a positive and significant effect on economic growth (GDP), Indonesian government debt (UPI) has an effect on economic growth (GDP), the effect of the variable Capital Expenditure (BM) on economic growth (GDP) in Indonesia shows a significant number. In this discussion section, the results of the data analysis that have been carried out previously will be explained. In general, the variables that affect the Defense Budget in Indonesia are the APBN, GDP and Economic Growth variables.

Based on the partial estimation results to answer empirical questions on the Defense Budget variable research

2010-2020 that the State Revenue and Expenditure Budget has a significant positive influence on the Defense Budget. The estimation results are in accordance with the initial hypothesis as evidenced by the t-count probability of $0.0201<, 0.0201$ $<0.05$.

The state revenue budget is the lifeblood of a country in running the government. According to Robert D Lee, Jr and Ronald W Johnson, the notion of a budget (budget) is "A document or a collection of documents that refer to the financial condition of an organization (family, corporation, government), including information on revenues, expenditures, activities, and purposes or goals". If translated into Indonesian, the definition of a budget is a document that shows the financial condition or condition of an organization (family, company, government) that provides information on income, expenses, activities and goals to be achieved.

The State Revenue and Expenditure Budget is a fiscal instrument used by the government to achieve the goals of the state, to realize development, equity, and people's welfare in a just manner. The government in implementing the APBN as the people's mandate, of course, must be managed with good governance so that the outputs generated for the programs outlined in the APBN can be realized and optimally benefited by the community.

The APBN posture includes government budget components which are grouped into three major groups, namely state revenues and grants, state expenditures, and financing. State revenues and grants consist of domestic revenues such as taxes and non-tax revenues, and grants, while state expenditures consist of central government expenditures and regional expenditures whose financing comes from domestic and foreign financing. (Pramono, 2021)

State spending is very important for people's lives, so the absorption of the state budget is expected to be carried out quickly, effectively, efficiently, transparently and accountably. Budget absorption that is not maximal and slow causes the government's public services to be hampered and its function as an instrument of fiscal policy, especially for economic stimulus, becomes ineffective. In Indonesia, if viewed from the side of expenditure in the government budget, one of them is allocated to the defense sector with the budget responsible for the Ministry of Defense consisting of personnel expenditure for payment of military and personnel salaries, expenditure on goods for care and maintenance and capital expenditure for modernization or purchasing. defense equipment (Yusgiantoro, 2014).

The defense spending budget is one part of the state revenue and expenditure budget (APBN). The Defense Budget often reflects how strong a country's defense is against threats from other parties and is a public budget allocated for various purposes related to a country's defense. The Defense Budget also gives an idea of how much defense spending should be spent in the following year. The amount of a country's defense spending budget reflects a country's ability to carry out its military activities. The purpose of holding defense spending is to provide a strong military defense for a country and maintain security for its citizens (White Paper on Defense of the Republic of Indonesia). This is in line with Adam Smith where the task of protecting the community needs to be carried out by the defense force which is the first obligation.

Theoretically, the APBN has a positive and significant effect on the defense budget, so that if the APBN is higher, the Defense Budget will also increase in mechanism. The defense sector is still a government budget priority where the Ministry of Defense budget is also the largest compared to other Ministries/Agencies and increases every year. However, things that need to be considered in an effort to increase the APBN which in the end will have a significant impact on the Defense Budget are in terms of domestic economic factors, namely economic growth (Smith, 1989). One of the requirements for increasing growth is to increase private and public investment and savings. Several other factors that need to be considered before expressing approval to increase military spending are, First, the limited financial condition of the government. This situation burdens the state's finances so that the increase in the APBN is difficult to realize due to limited funds and in the end also hampers the increase in 


\section{The Influence of the State Budget of Income and Expenditure on the Defense Budget}

the defense budget. Second, an increase in the defense budget could be counter-productive to the government's economic program to increase the rate of economic growth. Another aspect that needs to be considered in the calculation and planning of defense spending is inflationary pressures in the current year which will complicate things in the end.

It should be emphasized that the high budget allocation for defense expenditure shows that in general the superiority of military strength is still considered to be of strategic value in achieving national goals. The decrease in the defense budget in certain countries is basically a form of budget adjustment and does not represent a decrease in the desire for strength building. It is different with countries that have large defense budgets, of course they have large APBNs as well. Efforts to increase the defense budget must be accompanied by an increase in the state budget and vice versa.

The government's policies in an effort to increase the spending budget which ultimately increases the defense budget are:

1) The government's efforts to improve the state budget by reducing the budget deficit through increasing budgetary discipline, reducing subsidies and foreign loans gradually, increasing fair and honest progressive tax revenues, and saving expenditures.

2) The State Revenue and Expenditure Budget (APBN) is a fiscal instrument and if viewed in theory, government spending policy is part of fiscal policy as a form of government intervention in the economy. It should be noted that the defense economy, including defense expenditures/expenditures, has a close relationship with the fiscal sector (Yusgiantoro, 2014). Efforts to develop fiscal policy by taking into account the principles of transparency, discipline, fairness, efficiency, effectiveness, to increase state revenues. The main step taken by the government to strengthen fiscal policy is to increase government revenues with an emphasis on increasing tax revenues (Boediono, 2003). Until now, taxes are still the main mainstay of the government to increase revenue. Defense budgets in many countries are also financed by taxes. The government continues to strive to optimize potential tax revenue through expanding the taxpayer database and increasing tax compliance. Therefore, defense budget support from tax revenues must be accountable and auditable.

3) Taxes through their function as a function of the budget or revenue (budgetair) where taxes are one of the sources of funds used by the government and are useful for financing routine state tasks and carrying out development. Efforts to optimize state revenues with policies to encourage optimization of tax revenues so that the ratio of taxes per GDP is increasing. When GDP increases, tax revenue will increase even more. Mechanistically, an increase in GDP will affect the consumption pattern of the population which simultaneously causes an increase in tax revenue. In other words, an increase in per capita income will always be followed by an increase in the ability to pay taxes, so that tax revenues will increase. The economic surplus which is contributed by the state in the form of taxes will ultimately be used by the state to finance the defense budget.

4) Efforts to stimulate the economy by keeping the deficit within safe limits and controlling the primary balance. If the primary balance is negative if the total state income is smaller than state spending excluding interest payments on debt and vice versa. Healthy fiscal conditions were also supported by a reduction in the primary balance deficit. Maintain the target of the APBN deficit with closer coordination between revenue, expenditure and debt management units. The state budget deficit is the difference between state revenues and expenditures which tends to be negative, in the sense that state expenditures are greater than revenues. Efforts to fulfill the APBN deficit are carried out through a strategy of issuing State Securities (SBN) and foreign loans. Foreign loans are based on realistic estimates, adjusted to the state's financial situation and taking into account various things, such as sources of loans and debt requirements. Foreign loans include any state revenue, either in the form of foreign exchange or in the form of goods or services obtained from foreign lenders that must be repaid under certain conditions, as well as funds that can be disbursed quickly. It should be noted that foreign loans are not recommended because basically the state is trying to reduce the loan burden and even reschedule loans that are past due. Foreign loans also have an effect on rising interest rates, resulting in scarcity in the money market.

5) Improving the quality of state spending through increasing efficiency and effectiveness of state spending through improving the structure of state spending to become more productive and efficient in supporting the achievement of national development targets optimally. This is reflected in spending that is categorized as sustainable if in aggregate it is in line with the medium-term macroeconomic framework that results in a sustainable deficit/surplus and debt strategy. State expenditure is said to be efficient if it is able to achieve the results of the development priorities that have been determined with a budget allocation that is not wasteful and succeeds in achieving the targets of the national development program that have been set.

6) State revenue is endeavored primarily from domestic sources, because sources from abroad are strongly influenced by external factors and can reduce independence in financing development.

7) Efforts to reduce the provision of subsidies. Subsidies can lead to inefficient allocation of economic resources because often the end recipients are not from low-income groups. Another phenomenon is that the burden of energy and non-energy subsidies suppresses state spending because the energy subsidy burden is the largest compared to other expenditures. In 


\section{The Influence of the State Budget of Income and Expenditure on the Defense Budget}

the context of restructuring the state budget, reducing energy subsidies is the right step so that it can increase the portion of the state budget and expenditures.

\section{CLOSING}

Based on the results of the research that has been done and the comparison of the results of previous studies, the researchers found that how is the variability relationship that affects the increase in the defense budget. The defense spending budget is one part of the state revenue and expenditure budget (APBN). The defense budget often reflects how strong a country's defense is against threats from other parties and is a public budget allocated for various purposes related to a country's defense. The defense budget also gives an idea of how much defense spending should be spent for the following year. Theoretically, the APBN has a positive and significant effect on the defense budget, so that if the state budget is higher, the defense budget will also increase in mechanism.

When viewed from the side that gross domestic product (GDP) has a significant positive effect on the defense budget. GDP has an influence and attachment to state income, where the higher the level of income, the GDP will also increase. In the theory of economic development, it is known that GDP and state spending have a positive reciprocal relationship. If viewed in the macroeconomic context, government expenditure/expenditure is one of the variables forming gross domestic product (GDP). Defense spending has a strong relationship with GDP and is a good measure of showing the magnitude of the defense burden on the country's economy. The defense budget is a reflection of how strong a country is in building its military strength. With a strong economic condition, the military power will be strong supported by an adequate amount of budget as well.

In terms of economic growth, there are contradictions in both the estimation results and the theory, where based on the estimation results, economic growth has a significant negative effect on the defense budget. The Keynesian view is that the increase in government spending will encourage an increase in demand for various goods and services produced by the economy in aggregate so as to encourage economic growth. In other words, state spending, including defense spending, is an important and ideal policy tool used by the government in an effort to create and increase quality economic growth. However, in Wagner's law, namely the law of increasing expansion of public activity, where Wagner states that the actual economic growth that affects government spending is where in an economy if per capita income increases, the relative government spending will increase. This is in accordance with the ambition hypothesis by Castillo (2001) which states that the defense budget has a positive relationship with economic growth. Countries that have increasing economic growth have the ambition to increase their defense spending, in other words, the greater the strength and economic wealth of a country, the greater its defense spending. The state will pursue economic improvement and defense power is the highest goal of the state. In order to increase the defense budget, various efforts can be made by the government, including:

a. Increasing budget discipline, reducing subsidies and foreign loans gradually, increasing fair and honest progressive tax revenues, and saving expenditures.

b. Strengthening fiscal policy is to increase government revenues with an emphasis on increasing tax revenues

c. Efforts to stimulate the economy by keeping the deficit within safe limits and controlling the primary balance. Efforts to fulfill the state budget deficit are carried out through a strategy of issuing state securities (SBN) and foreign loans

d. $\quad$ Efforts to reduce subsidies.

e. Coordinated and synergistic management of macro and microeconomic policies to determine reasonable interest rates, controlled inflation rates, stable and realistic rupiah exchange rates. High interest rates will limit credit and ultimately reduce economic growth.

f. Develop industrial, trade and investment policies to increase global competitiveness

g. Increasing the number of exports and imports to increase the country's foreign exchange

h. Efforts to increase investment will increase the rate of growth so that GDP will increase. Investment funds are obtained from government and public savings

i. The increase in industry in work and various aspects of the country's economy, followed by an increase in the productive workforce, technological progress and exports

j. The growth of household consumption is expected to increase every year. Stagnant growth in household consumption greatly affects economic growth. Household consumption includes people's purchasing power in spending their money.

\section{REFERENCES}

1) Agus Damar Jaya, S. ., Lukman Yudho Prakoso, Purwanto., Dohar Sianturi, Resmanto Widodo Putro, \& Agus Damar Jaya Lukman Yudho Prakoso, Purwanto., Dohar Sianturi, Resmanto Widodo Putro, S. (2020). Sea Defense Strategy of 
The Influence of the State Budget of Income and Expenditure on the Defense Budget

Anti-Submarine on We Island. International Affairs Global Strategy, 81(Defense Strategy), 15-20. https://doi.org/10.7176/IAGS/81-03

2) Anggoro, Kusnanto. 2005. Introductory Paper in Public Discussion with the Theme "Defense and Security Management": Management of State Defense (and Security) Resources. Jakarta: Propatria Institute

3) KITA 2018 State Budget Performance and Facts January 2019 Edition Ministry of Finance Law on State Treasury, Law Number 1 Year 2004 LN Number 5 Year 2004 TLN Number 4355 Central Government Financial Statements 2012-2019

4) Ashley J. Tellis, Janice Bially, Christopher Layne and Melissa McPherson, Op. cit., p. 137

5) Atmadja, Arifin P. Soeria. 2009. Public Finance in Legal Perspective, Theory, Criticism and Practice. Jakarta: RajaGrafindo Persada Deger, Saadet and Somnath Sen. 1995. Military Expenditure And Developing Countries.

6) Dipua, A., Harahap, N., Puspitawati, D., Aminuddin, F., Prakoso, L. Y., Brawijaya, U., \& Defense, U. (2021). Sea Defense Strategy the Indonesian Navy in Dealing with the South China Sea Conflict. ITALIENISCH, 11(2), 120-126. https://doi.org/https://doi.org/10.1115/italienisch.v11i2.103

7) Economics and Military Expenditures in Indonesia 1981-2018. Bogor: Elsevier Science B. V: Handbook Of Defense Economics, Volume 1.

8) Gujarati, D.N. 2003. Fundamentals of Econometrics. Jakarta: Erlangga

9) Hermawan, Asep. 2004. Quantitative Paradigm Business Research. Jakarta: PT Gramedia Widia Sarana Indonesia Jakarta: Ministry of Defense of Indonesia. Jakarta: Indonesian Defense University

10) Jhingan M.L., (2004). Economic Development and Planning, Jakarta: Rajawali Press Indonesian Ministry of Defense. (2015). Indonesian Defense Posture Book. Jakarta: Indonesian Ministry of Defense.

11) Junaidi, M. E., Prakoso, L. Y., Eka, M., \& Yudho, L. (2021). Pancasila as the Basis for Indonesia's Universal Defense. Journal of Social and Political Sciences, 4(2), 148-154. https://doi.org/10.31014/aior.1991.04.02.283

12) Love Prihantoro Zakariya, Lukman Yudho Prakoso, Ratna Damayanti, A. D. (2019). Public Policy Analysis of Defense Areas and Defense Area Plan In Grati Pasuruan. The 3th Indonesia International Defense Science Seminar, 2(University of Defense), 483-490.

13) Indonesian Ministry of Defense. (2015). Indonesian Defense White Paper. Jakarta:

14) Lincoln, A. (2004). Economic development. Yogyakarta: STIE Publisher in Economics

15) Listiyono, Y., Prakoso, L. Y., \& Sianturi, D. (2021). Marine Defense Strategy in Securing Indonesian Archipelago Sea Lanes to Realize Maritime Security and Maintain Indonesian Sovereignty. Marine Defense Strategy, 5(3), 103-116.

16) Lukman Yudho Prakoso 1 Gerald Theodorus L. Toruan 3 , Dohar Sianturi 4, and Ratna Damayanti 5, S. 2. (2019). Defense State Model for Facing Threats of Radicalism and Terrorism in Indonesian Higher Education-. The 3th Indonesia International Defense Science Seminar, 2(DEFENSE THE STATE).

17) Mangkosoebroto, Guritno. (2001). Public Economics Third Edition, Yogyakarta: BPFE UGM Putri, Yuaninda Laksmitasari Yuli Handoyo. 2020. Growth Causality Study, Faculty of Economics, University of Jember. Groups: Indonesia. Erlangga Publisher

18) Prakoso, L. Y., Suhirwan, Sianturi, D., Adriyanto, A., \& Damayanti, R. (2019). Implementation of the policy on the Implementation of the Tasks of the Indonesian National Armed Forces in Overcoming Natural Disasters. Proceedings of ICDM 2019 Volume 2, 2(disaster).

19) Pramono, A.: B., \& editor, L. Y. P. (2021). Politics and national defense. Publisher: CV. Academic Global Script,.

20) Sanusi, Anwar. 2011. Business Research Methods. Jakarta: Four Salemba

21) Setaidji, Agus. 2020. The Defense Economy: Confronting a Sixth Generation War.

22) soerarso', S. prasojo, \& Prakoso, L. Y. (2021). public policy POLICY COMMUNICATION OF JAKARTA CAPITAL SPECIAL GOVERNMENT (Qualitative Descriptive Study of Negotiation of Regional Government Pavement Revitalization Policy on Jalan Kemang Raya, Special Capital Region of Jakarta). Journal of Research Innovation, 2(3), 955-964.

23) Sugiyono. 2011. Quantitative, Qualitative and R\&D Research Methods. Bandung: Afabeta Sukirno, Sadono. (2006). Development Economics Second Edition. Media Prenada

24) Suhirwan. Wuri Retno Martani, L. Y. P., Suhirwan., Lukman Yudho Prakoso, \& Wuri Retno Martani. (2020). Indonesian Navy as a Maritime Command Center Sea Defense Strategy. Public Policy Administration Research, 10(sea defense strategy), 33-39. https://doi.org/10.7176/PPAR/10-2-03

25) Suparmoko, M. (2011). State Finance in Theory and Practice. Publishing Agency Faculty of Economics, University of Gajah Mada: Yogyakarta.

26) Thomas W. Smith, History and International Relations, London \& New York: Routledege, 1999, p. 135.

27) Todaro, Michael, P. (2008). Economic Development Ninth Edition. Volume 1, Jakarta: Defense University.

28) Wardhono, Aditya. 2004. Introduction to Econometric Theory and Applications. First Edition. YKPN

29) Yusgiantoro, Purnomo. 2014. Defense Economics. Jakarta: PT Gramedia Media Pustaka 
The Influence of the State Budget of Income and Expenditure on the Defense Budget 